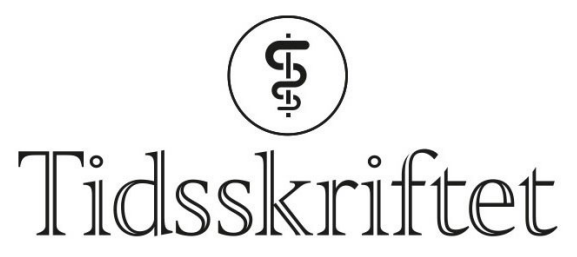

DEN NORSKE LEGEFORENING

\title{
Hemosiderinavleiringer i hjernen
}

MEDISINEN I BILDER

STEPHAN JOHANNES SCHÜLER

E-post:Stephan.Schuler@hnt.no

Nevrologisk avdeling

Sykehuset Namsos

Stephan Johannes Schüler (f. 1967) er utdannet spesialist i nevrologi fra Tyskland, har doktorgrad derfra og er avdelingsoverlege.

Forfatter har fylt ut ICMJE-skjemaet og oppgir ingen interessekonflikter.

\section{KJELL ARNE KVISTAD}

Klinikk for bildediagnostikk

St. Olavs hospital

Kjell Arne Kvistad (f. 1960) er dr.med., spesialist i radiologi og seksjonsoverlege.

Forfatter har fylt ut ICMJE-skjemaet og oppgir ingen interessekonflikter.

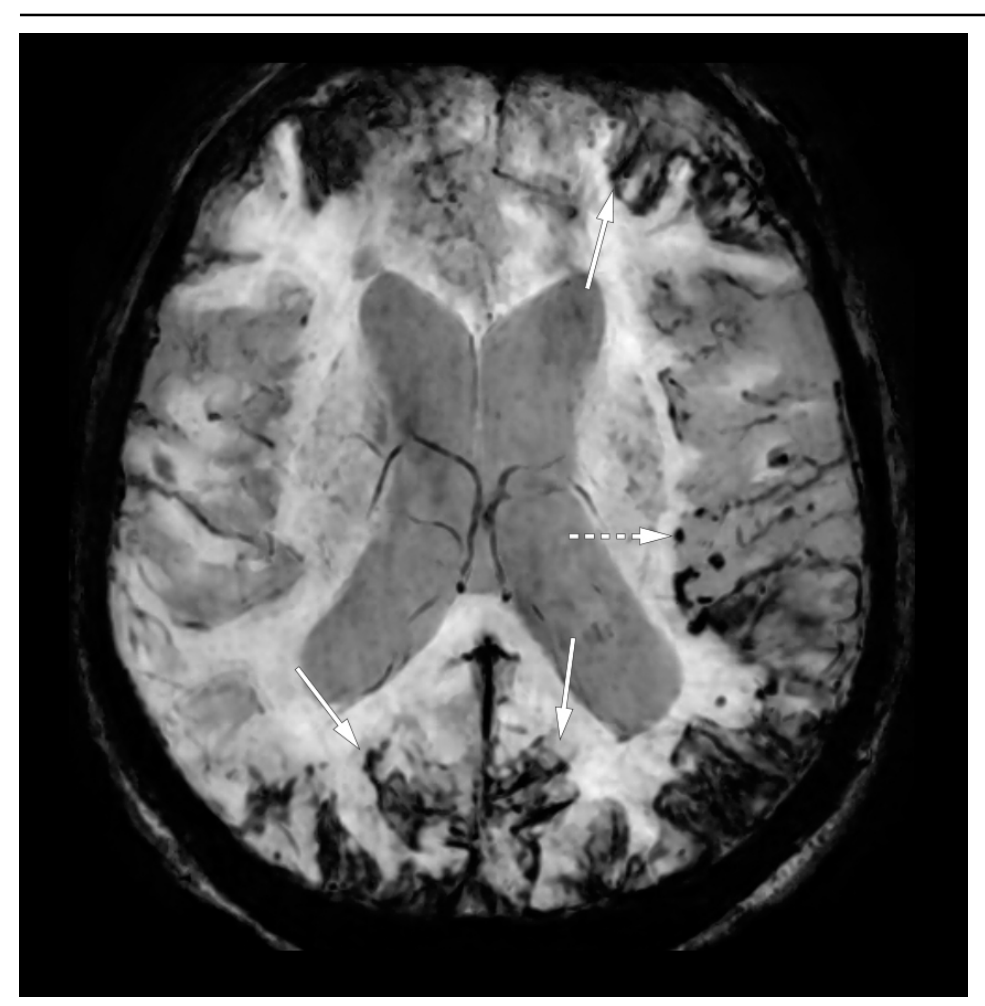

En mann i go-årene fikk fire år før innleggelsen en venstresidig parenkymatøs

hjerneblødning parietalt med gjennombrudd til subaraknoidalrommet. Pasienten var etter det selvhjulpen, men hadde moderate kognitive utfall.

Tre måneder før innleggelse fikk pasienten et gradvis fall i fysisk og kognitiv funksjon som førte til at han ble sengeliggende og pleietrengende. 
Ved den initiale nevrologiske undersøkelsen fantes ingen sikker fokal patologi, men pasienten fremsto som forvirret og afatisk.

CT caput, thorax, abdomen og bekken var normal. Spinalpunksjon viste ingen tegn til infeksjon eller inflammasjon. Sykehistorien kunne passe med Creutzfeldt-jakobs sykdom, men protein 14-3-3 i spinalvæske, som brukes som biomarkør for tilstanden, var normal. Betaamyloid, totaltau, fosfotau i spinalvæske var forenlig med Alzheimers sykdom. Dette er biomarkører som brukes for å skille Alzheimers sykdom fra normal aldring. EEG viste generell langsom aktivitet (theta), noe som tyder på en uspesifikk hjernefunksjonsforstyrrelse.

Susceptibilitetsvektede MR-bilder i aksialplanet viste utbredte hemosiderinavleiringer på hjerneoverflaten (heltrukne piler) forenlig med superficiell hemosiderose, tallrike mikrohemoragier i hjerneparenkymet (stiplet pil), de fleste subkortikalt i venstre hemisfre. Mikrohemoragier i forbindelse med en tidligere blødning er typisk for en amyloid angiopati.

Overfladisk hemosiderose av den «klassiske typen» er en sjelden, men potensielt alvorlig tilstand som følge av leptomeningeal akkumulering av hemosiderin på overflaten av cerebellum, rundt hjernenerver og ryggmargen. Etiologisk foreligger en blødning (akutt eller kronisk) i subaraknoidalrommet.

Ved den kortikale typen er hemosiderose lokalisert supratentorielt (over den cerebrale konveksiteten), og en cerebral amyloid angiopati anses spesielt hos eldre som en etiologisk nøkkelfaktor. Cerebral amyloid angiopati forårsakes av amyloidavleiringer i hjernekar som fører til mikroaneurismer og $\varnothing \mathrm{kt}$ blødningstendens (mikroblødninger eller større hjerneparenkymblødninger). Cerebral amyloid angiopati er i seg selv assosiert med en $\emptyset \mathrm{kt}$ risiko for demensutvikling.

Typiske kliniske funn ved den klassiske typen inkluderer blant annet hørselstap, ataksi, pyramidebanetegn (spastisitet, pareser) og hodepine. Ved den kortikale typen finnes (transiente) fokale nevrologiske symptomer, men også demensutvikling(1).

Prognostisk ser man ved en cerebral hemosiderose som regel en langsom progrediering, men også en rask forverring med fatal utgang er beskrevet (2).

Den uttalte hemosiderosen hos denne pasienten vurderes derfor til å være en medvirkende årsak til den usedvanlig raske progredieringen av hans demens. Pasienten døde noen måneder etter at diagnosen var stilt.

\section{LITTERATUR:}

1. Charidimou A, Linn J, Vernooij MW et al. Cortical superficial siderosis: detection and clinical significance in cerebral amyloid angiopathy and related conditions. Brain 2015; 138: 2126 - 39 . [PubMed][CrossRef]

2. Lanska DJ. Disorders of the special senses in the elderly. I: Nair A, Sabbagh M, red. Geriatric neurology. Chichester, West Sussex: John Wiley \& Sons, 2014:396-459.

Publisert: 21. august 2017. Tidsskr Nor Legeforen. DOI: 10.4045/tidsskr.16.1026

Mottatt 24.11.2016, første revisjon innsendt 31.3.2017, godkjent 9.5.2017.

(C) Tidsskrift for Den norske legeforening 2020. Lastet ned fra tidsskriftet.no 